\title{
SHADING EFFECTS ON GROWTH AND PARTITIONING OF PLANT BIOMASS IN PASPALUM CONJUGATUM BERG.
}

\author{
I.B. IPOR \\ Universiti Pertanian Malaysia, Kampus Bintulu, \\ P.O. Box 396, 97008, Bintulu, Sarawak, Malaysia \\ and \\ C.E. PRICE \\ Imperial College, Silwood Park, Ascot, Berkshire \\ SLS 7PY, England
}

\begin{abstract}
Glasshouse studies were carried out to determine the effect of shading on the growth and partitioning of plant biomass in Paspalum conjugatum Berg. The invidual leaf rate expansion, final leaf are, specific leaf area, and the whole plant vegetative growth pattern, dry-matter production, leaf area as well as biomass partitioning were significantly influenced by shading. At the $75 \%$ level of shading, $P$. conjugatum produced the highest values of leaf weight ratio, specific leaf area and leaf area ratio. Individual leaf assessment revealed that shading significantly increased the final leaf area, duration of leaf expansion and specific leaf area.
\end{abstract}

\section{INTRODUCTION}

Weeds are often considered as very competitive plants. Weeds competing for light, water and nutrient have adverse effects on crop growth and yield. The availability of these resources influences the physiological, morphological and competitive responses of both weeds and crops.

The effects of light on weed growth vary between species. Generally, these effects can be distinguished on the basis of their physiological characteristics. Among the common response of plants upon shading in general, are the alteration of leaf size (Bjorkman and Holmgren 1966), internode extension, number of branching (Vince-Pruce 1977) and stem elongation rate (Morgan and Smith 1981).

Paspalum conjugatum Berg, is an important, stoloniferous creeping perennial weed in Malaysia and in many regions of Southeast Asia. It grows well in the moist, fertile soils of agricultural fields, roadsides and wastelands. $P$. conjugatum grows profusely in most estates such as rubber, oil palm, cocoa and coconut (Holm et al. 1977). It can tolerate, survive and grow under shade condition (Beetle 1974; Ward and Woolhouse 1986). $P$. conjugatum possesses several important characteristics 
that enable it to interfere with crop growth: rapid growth with extensive stolon formation, early and profuse tillering, heavy seed production and readily rooting at most nodes whenever in contact with the soil surface. However, little information has been reported on the morphological and physiological response of $P$. conjugatum when exposed to different environmental conditions. The present study was conducted to determine the effects of shade on the growth of $P$. conjugatum in different shade levels.

\section{MATERIALS AND METHODS}

\section{Plant materials and growing conditions}

Uniformed size seedlings of two leaf stage were transplanted into $10-\mathrm{cm}$ diameter pots filled with John Innes No. 1 compost mixture. Watering was carried out daily and $15 \mathrm{ml}$ of nutrient solution ( 7:7:7 NPK foliar fertilizer) was given twice a month.

The temperature of the glasshouse was maintained at $30 \pm 40^{\circ} \mathrm{C}$ during the day and $12 \pm 3^{\circ} \mathrm{C}$ at night. The plants were exposed to sunlight and supplemented with 12 hours of fluorescent white light each day. These plants were grown under three shade levels: $0 \%$ (control), 50\% and 75\%. Single and double layers of green nettings (Netlon, UK) were used to cover the cages to obtain $50 \%$ and $75 \%$ shade, respectively. The light intensities of the shading regimes were regularly checked with Skye Light meter (Skye Instrument Limited, UK).

\section{Harvesting and growth analysis}

Ten plants from each light regimes were used to determine weekly increments in plant height or length, leaf number, internode length, stolon and node numbers.

The other group of plants were harvested at 35 and 42 days after transplanting to determine the leaf area and total dry weight $\left(65^{\circ} \mathrm{C}\right.$, oven-dried). In addition, dry weights of plant parts were also determined on the 42 nd-day of harvest. Dry-matter production and biomass allocation patterns of the three shade levels were compared using mathematical growth analysis techniques (Kvet et al. 1971; Patterson et al. 1979). Data from 42nd-day harvest were used to calculate leaf weight ratio, shoot weight ratio, specific leaf area and leaf area ratio. Calculation of dry-matter production, net assimilation rate and leaf area duration were based on 35th-day and 42nd-day harvests.

All experiments were repeated twice and data were subjected to analysis of variance. Duncan's Multiple Range or Least Significant Difference (LSD) test was used to determine significant differences among the mean values for each treatment. 


\section{Growth of individual leaf}

The leaf shape was traced on a white paper and cut out with scissors. The area traced was taken as the leaf area and determined with an optomax tracer. Leaf measurements were made on alternate leaves, starting from the second leaf till the sixteenth leaf. Measurements were made at the time of leaf appearance, i.e. when the leaf was sufficiently distinct from the apical bud so that it could be measured without damaging the bud. The measurement was continued until the area remained constant after three successive readings. An example of the measurements on one plant is given in Figure 1. The individual leaf was finally harvested and oven dried at $65^{\circ} \mathrm{C}$ for determination of dry weight.

Two sets of experiments were arranged in completely randomized blocks with ten replicates. Final leaf size, duration of leaf expansion, weighed mean growth rate and specific leaf area of each individual leaf were calculated and subjected to variance analysis. Means were compared using the LSD test.

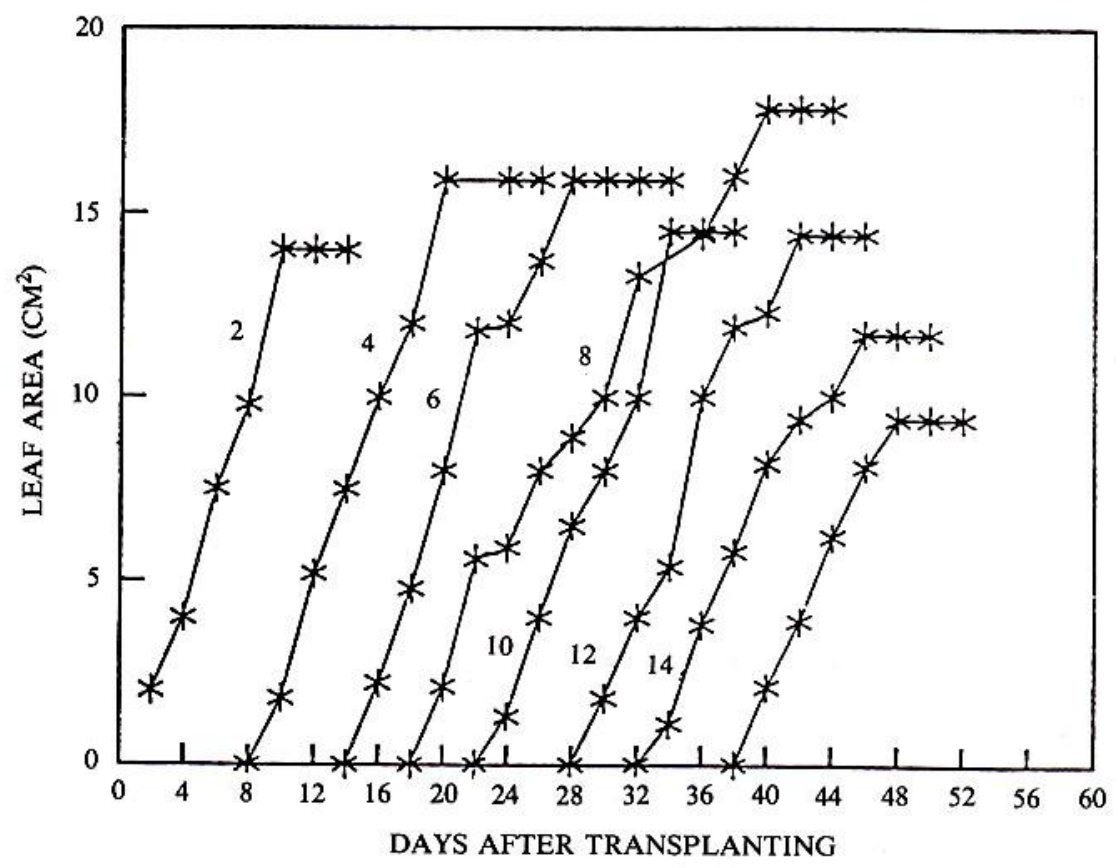

Figure 1. Example of measurement of leaf area of individual leaves of $P$. conjugatum. Each number indicates leaf position. 


\section{RESULTS AND DISCUSSION}

The number of leaves recorded for $P$. conjugatum was significantly influenced by light intensity (Figure 2). Thus, plants at $0 \%$ shade had significantly more leaves than those provided with $50 \%$ and $75 \%$ shade. However, height of plants at $75 \%$ shade was significantly greater than those at $0 \%$ and $50 \%$ shade, 35 days after transplanting (Figure 3). The shortest plant height were all recorded at $0 \%$ shade. Reducing light intensity to $75 \%$ had significantly decreased the number of stolons (Figure 4). Plants at $0 \%$ shade produced more stolons as compared with those at 50\% shade, 35 days after transplanting. Bjorkman (1968) and Ishimine etal. (1985) noted that reduced light levels to a certain degree would result in increased stem extension of Solidago virgaurea L. and height of vaseygrass (Paspalum urvillei Steud.), respectively. However, further reduction of light suppressed the plant growth. This pattern of growth was also reported by Soerjani (1970) and Moosavi and Dore (1979) in their work on Imperata cylindrica. Decreasing the light intensity tends to increase the total dry weight of $P$. conjugatum (Table 1). Plants grown under $0 \%$ shade produced the highest total dry weight, followed by $50 \%$ and $75 \%$

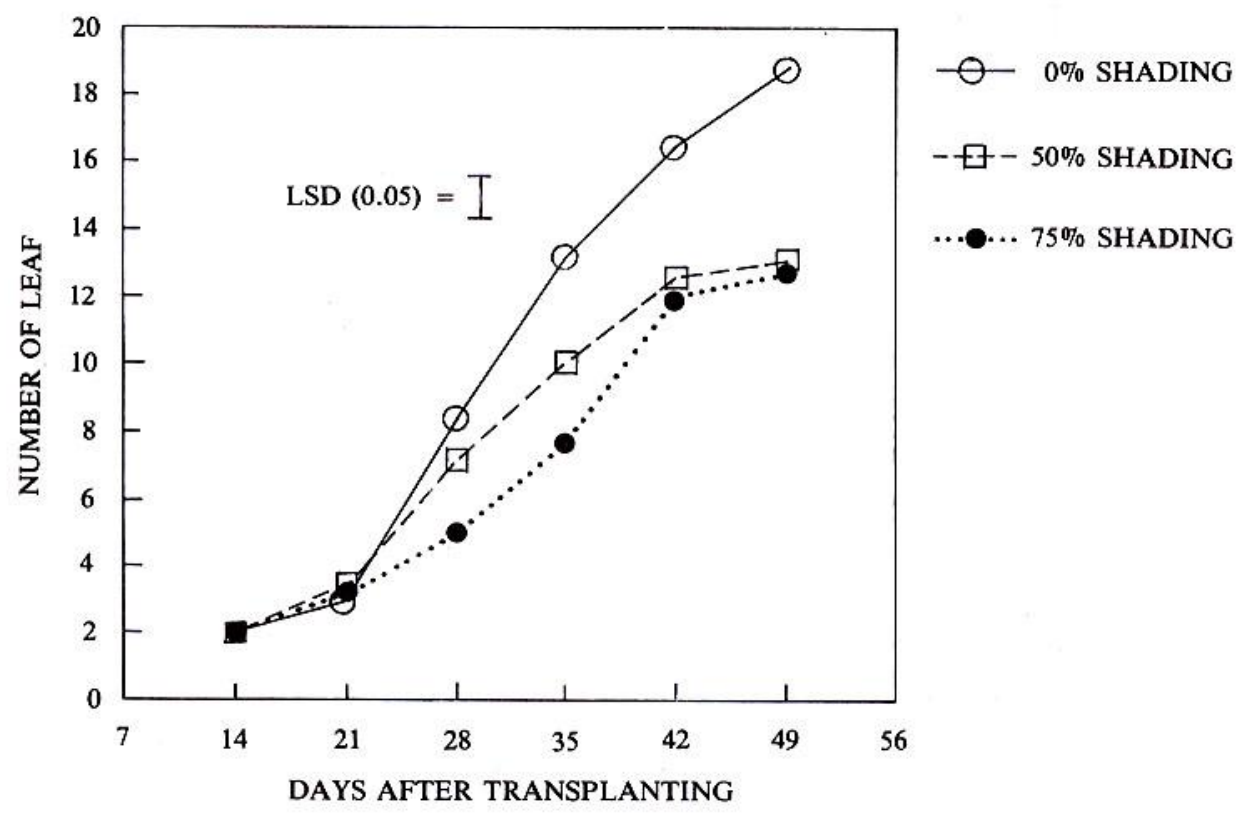

Figure 2. Effect of shading on leaf number of P. conjugatum. 
Shading effects on growth and partitioning of plant biomass - I.B. Ipor \& C.E. Price

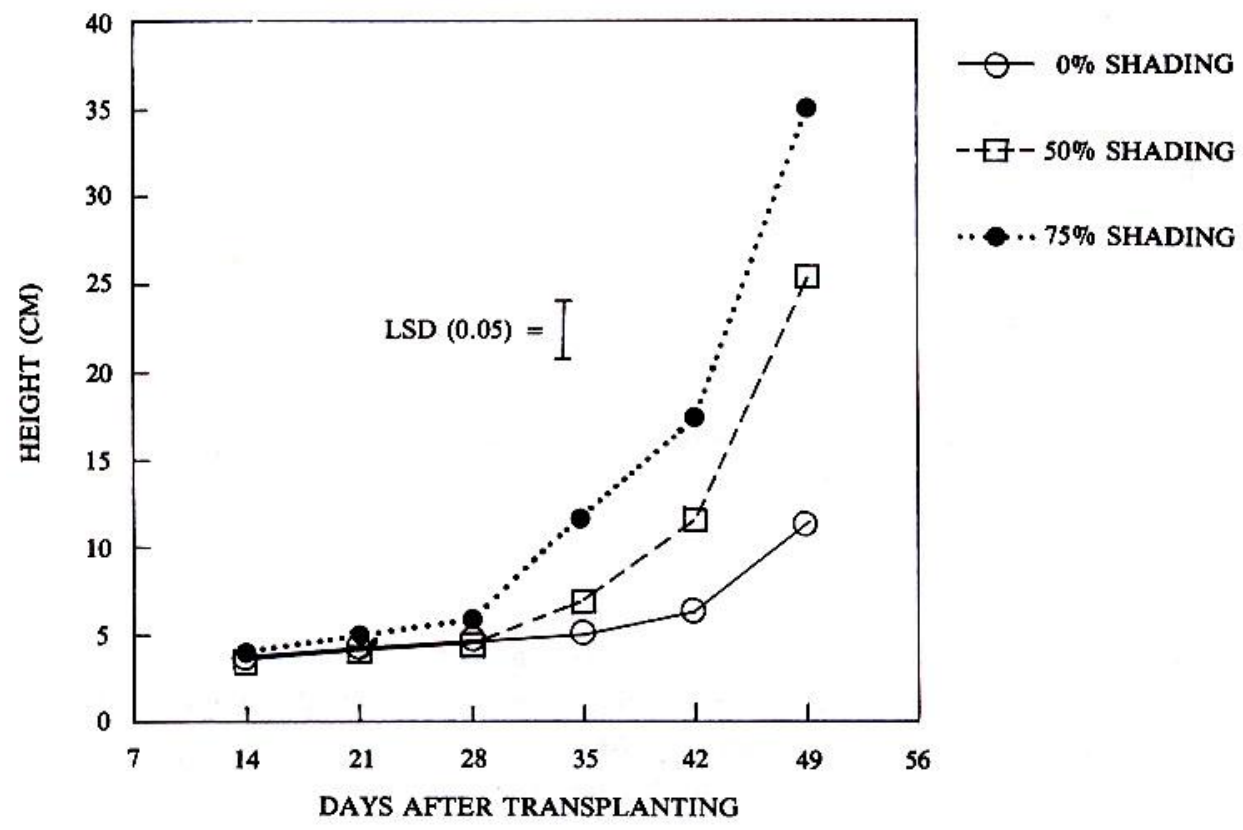

Figure 3. Effect of shading on the height of $P$. conjugatum.

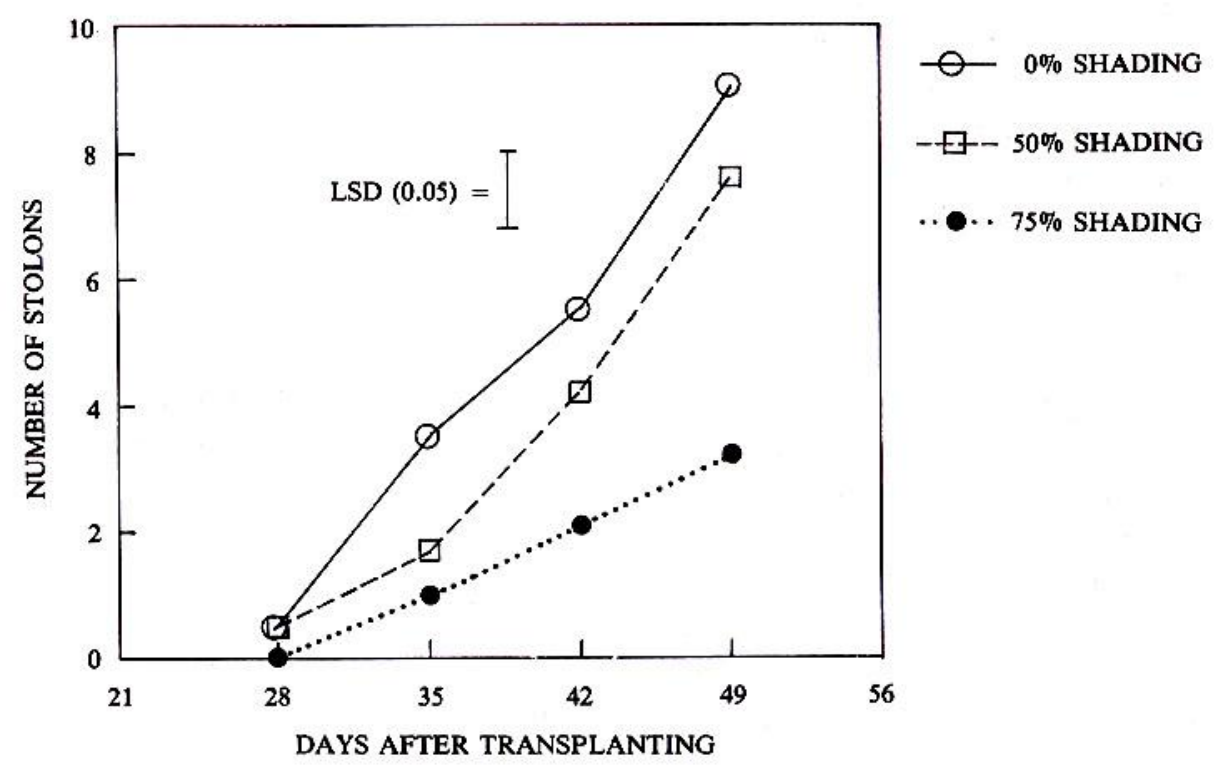

Figure 4. Effect of shading on stolon number of $P$. conjugatum. 
Table 1. Effect of shading on vegetative growth, leaf area production and biomass allocation in $P$. conjugatum (42nd day harvest).

\begin{tabular}{rllllllr}
\hline \hline $\begin{array}{l}\text { Shade } \\
\text { level }\end{array}$ & $\begin{array}{l}\text { Plant } \\
\text { dry } \\
\text { weight } \\
(\mathrm{g})\end{array}$ & $\begin{array}{l}\text { Total } \\
\text { leaf } \\
\text { area } \\
\left(\mathrm{cm}^{2}\right)\end{array}$ & RWR & SWR & LWR & SLA & LAR \\
\hline $0 \%$ & $7.20 \mathrm{a}$ & $279 \mathrm{c}$ & $0.48 \mathrm{a}$ & $0.29 \mathrm{a}$ & $0.23 \mathrm{~b}$ & $363 \mathrm{c}$ & $84 \mathrm{c}$ \\
$50 \%$ & $6.92 \mathrm{a}$ & $433 \mathrm{a}$ & $0.48 \mathrm{a}$ & $0.29 \mathrm{a}$ & $0.23 \mathrm{~b}$ & $463 \mathrm{~b}$ & $108 \mathrm{~b}$ \\
$75 \%$ & $2.79 \mathrm{~b}$ & $344 \mathrm{~b}$ & $0.24 \mathrm{~b}$ & $0.28 \mathrm{a}$ & $0.48 \mathrm{a}$ & $522 \mathrm{a}$ & $252 \mathrm{a}$ \\
\hline
\end{tabular}

Within each column, value sharing the same letter are not significantly different at $5 \%$ level, according to Duncan's multiple range test.

shade levels. Total dry matter of three populations of cogon grass [Imperata Cylindrica (L.) Beauv.] decreased three fold at $56 \%$ of full sunlight and 20 fold at $11 \%$ of full sunlight (Patterson 1980b). Imperata cylindrica that grew with $11 \%$ of full sunlight had a leaf area ratio 2.5 times greater than those grown in full sunlight.

The leaf area of the $P$. conjugatum increased correspondingly with increase in shade levels (Table 1). The highest leaf area was $433 \mathrm{~cm}^{2}$ from $50 \%$ shade, followed by $344 \mathrm{~cm}^{2}$ from $75 \%$ and $274 \mathrm{~cm}^{2}$ from $0 \%$ shade. $P$. conjugatum is a C4 grass native to shaded habitats or shade tolerant species (Ward and Woolhouse 1986) which normally produced linear thin leaves. The highest value of leaf areas of plants from $50 \%$ shade was possibly due to a sufficient number of large leaves as compared with those from $75 \%$ shade. Leaves at $0 \%$ shade were reduced in size although the number exceeded from those in the other light regimes. The reduction in total leaf area with $75 \%$ shade may have resulted from a reduction in the leaves.

Partitioning of plant biomass into roots and leaves differed significantly among the plants under the three shade levels. At $0 \%$ and $50 \%$ shade levels, the plants partitioned more biomass into roots and stems than the other two light regimes (Table 1). RWR (root weight ratio) and SWR (shoot weight ratio) were highest at $0 \%$ and $50 \%$ shade. Plants at $75 \%$ shade, partitioned most biomass as leaf area was also greatest in $75 \%$ shade, as indicated by their high specific leaf area and leaf area ratio values. The values differed significantly among the three shade levels. Plants at $75 \%$ shade had the highest leaf area ratio followed by those at $50 \%$ shade. Leaves produced under shade conditions were generally thinner than those produced in unshaded treatment (Blackman and Black 1959). The concomitant increases in specific leaf area and leaf weight ratio resulted in substantial increases in the leaf area ratio which means that the amount of leaf area per unit of plant 
weight was increased by shading. Morgan and Smith (1978) reported that the LAR increased by 38\%, after 32 days in the shade treatment (15\% sunlight) of Cyperus rotundus grown for 30 days compared with full sunlight conditions. Leaf area ratio and specific leaf area of Veronica chamaedrys, $V$. montana and $V$. offlcinalis were also increased at low radiance (Dale and Causton 1992). Increase in leaf area ratio with shading was an adaptation to low light at the whole-plant level because it reflected a greater allocation of plant biomass to photosynthetic tissue and a greater distribution of this tissue as light-intercepting structure in the form of the leaf area (Patterson 1980b).

Analysis of the components of dry-matter production, net assimilation rate and leaf area duration at the three shade levels indicated that dry-matter production and net assimilation ratio showed the highest value at $0 \%$ and $50 \%$ shade for leaf area duration (Table 2). Leaf area duration significantly differed among the three shade levels.

Table 2. Effect of shading on dry-matter production, net assimilation rates, leaf area duration of $\mathrm{P}$. conjugatum during the 35th-to-42nd-day interval.

\begin{tabular}{lccc}
\hline \hline $\begin{array}{l}\text { Shade } \\
\text { level }\end{array}$ & $\begin{array}{c}\text { DMP } \\
(\mathrm{g})\end{array}$ & $\begin{array}{c}\text { NAR } \\
\left(\mathrm{mg} . \mathrm{cm}^{2} \text {.day }\right)\end{array}$ & $\begin{array}{c}\text { LAD } \\
\left(\mathrm{cm}^{2} . \text { day }\right)\end{array}$ \\
\hline $0 \%$ & $3.74 \mathrm{a}$ & $0.70 \mathrm{a}$ & $5443 \mathrm{c}$ \\
$50 \%$ & $2.88 \mathrm{ab}$ & $0.32 \mathrm{~b}$ & $8546 \mathrm{a}$ \\
$75 \%$ & $1.42 \mathrm{~b}$ & $0.21 \mathrm{~b}$ & $6701 \mathrm{~b}$ \\
\hline
\end{tabular}

Within each column, values sharing the same letter are not significantly different at $5 \%$ level, according to Duncan's multiple range test.

In general, decreasing the light intensity tends to increase the final leaf areas (Figure 5). The largest size of individual leaves was always found at 75\% shade. Newton (1963) observed a similar trend as reduction in light significantly reduced the final areas of individual leaves of cucumber. The final areas of individual leaves in all treatments showed a characteristic variation with leaf position with an increase in size up to about leaf six. Final leaf sizes of different leaves across shading treatment were significantly different except for leaf 12 and 14 under $0 \%$ and 50\% shade. Leaf areas were maximum at leaf 6 of plants at 75\% and 50\% shade while this was at least 4 of plants at $0 \%$ shade. Dennet et al. (1979) observed that the final leaf area increased with leaf position (numbered from the base) up to the 8th leaf of faba beans. A similar general pattern of variation in final leaf area with leaf position had been reported for sunflower (Yegappan et al. 1982), maize (Thiagarajah and Hunt 1982) and sugar beet (Milford et al. 1985). 


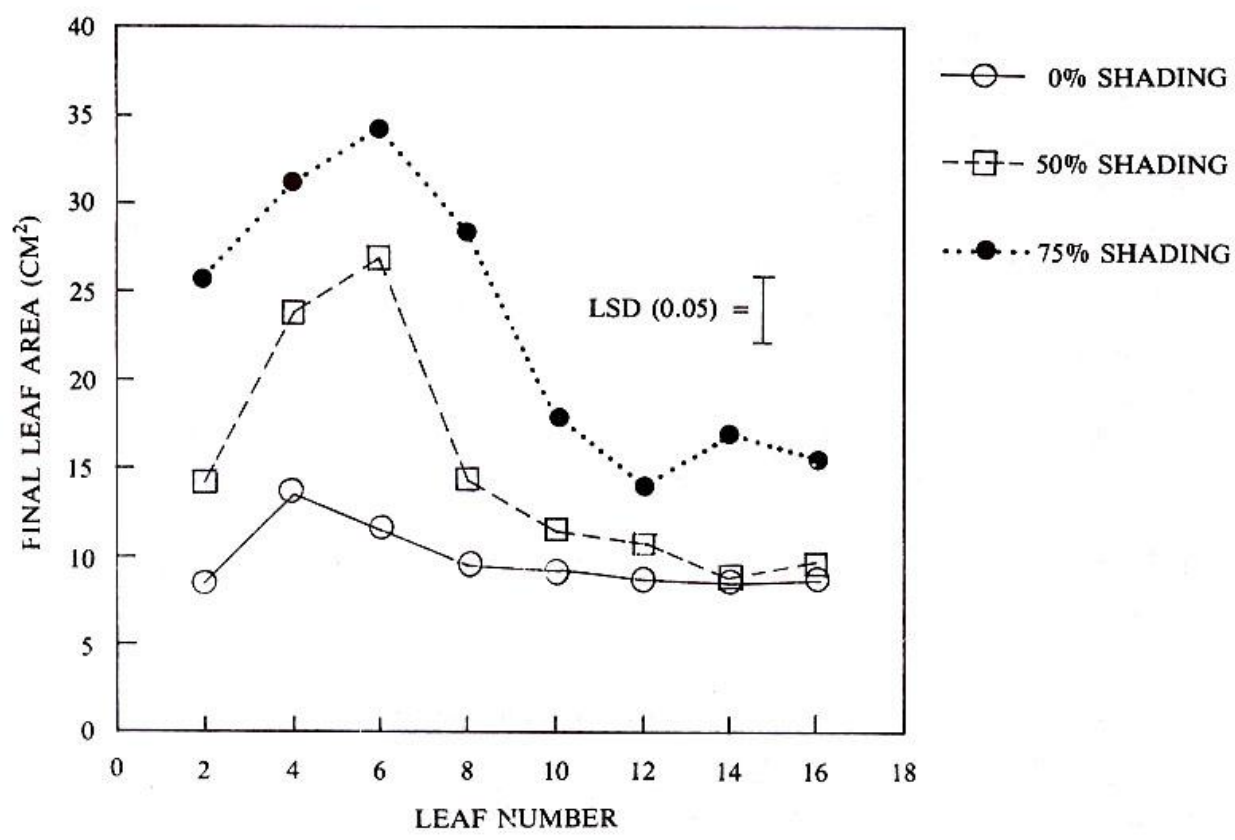

Figure 5. Effect of shading on final leaf area of $P$. conjugatum.

The duration of expansion increased significantly with increasing shade and decreased with increasing leaf number (Figure 6). Leaves at both 50\% and $75 \%$ shade took a significantly longer period to reach their maximum size. Initially, the duration of expansion was increased with increasing leaf number but decreased after leaf 6 for $50 \%$ and $75 \%$ shade. The results revealed that leaves from higher shading particularly at the earlier growth stage needed longer time to reach their maturity. Much of the variations in final leaf area with leaf position or shade level were associated with changes in the weighed mean growth rate rather than with changes in the duration of expansion. Weighed mean growth tended to increase with decrease in light intensity (Figure 7). At 75\% shade, the weighed mean growth rate was significantly higher than at $0 \%$ and $50 \%$ shade. Weighed mean growth rate reached a maximum of $1.3 \mathrm{cmVday}$ for leaf 6 at $75 \%$ shade.

The specific leaf area was significantly increased by increase in shade (Figure 8). For example, specific leaf area of leaves under $75 \%$ shade differed greatly compared with other shade treatments. Maximum specific leaf areas were 299, 318 and 334 for 0\%, $50 \%$ and $75 \%$ shade, respectively. It was also observed that the 
Shading effects on growth and panitioning of plant biomass - I.E. Ipor \& C.E. Price

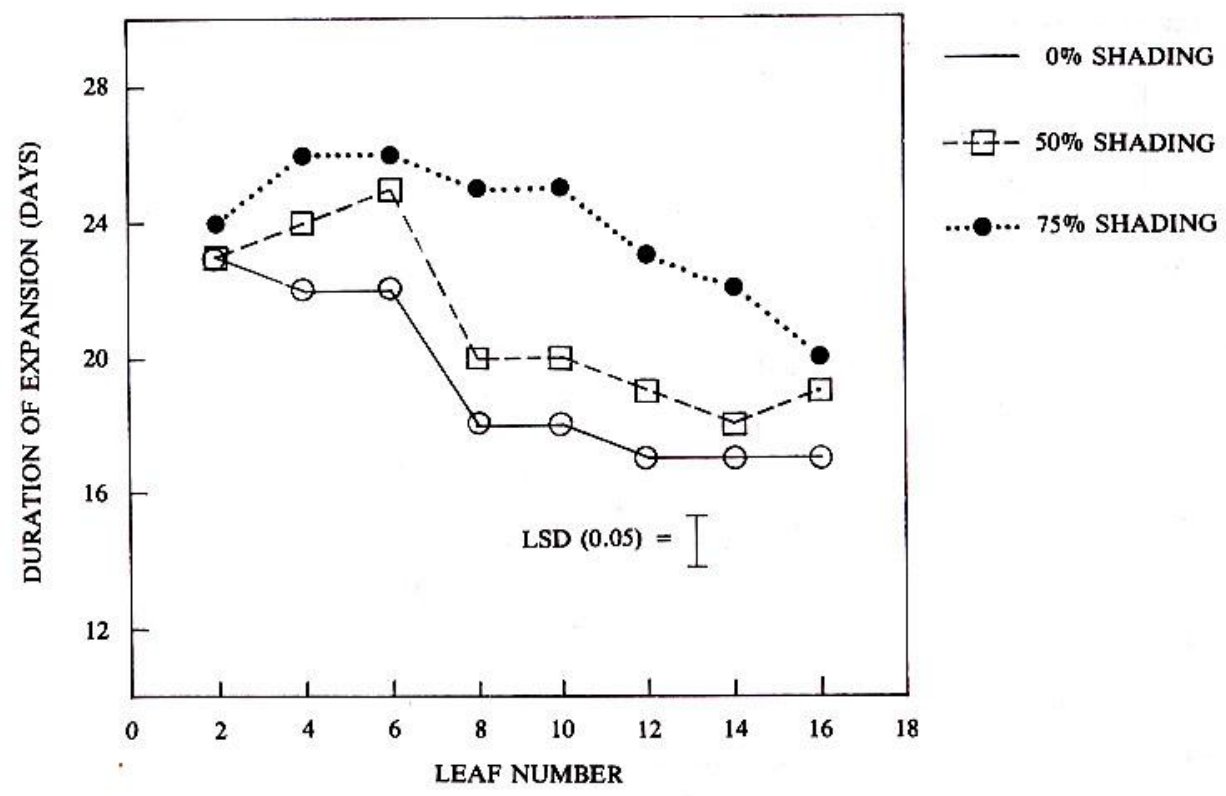

Figure 6. Effect of shading on the duration of expansion of $P$. conjugatum leaves

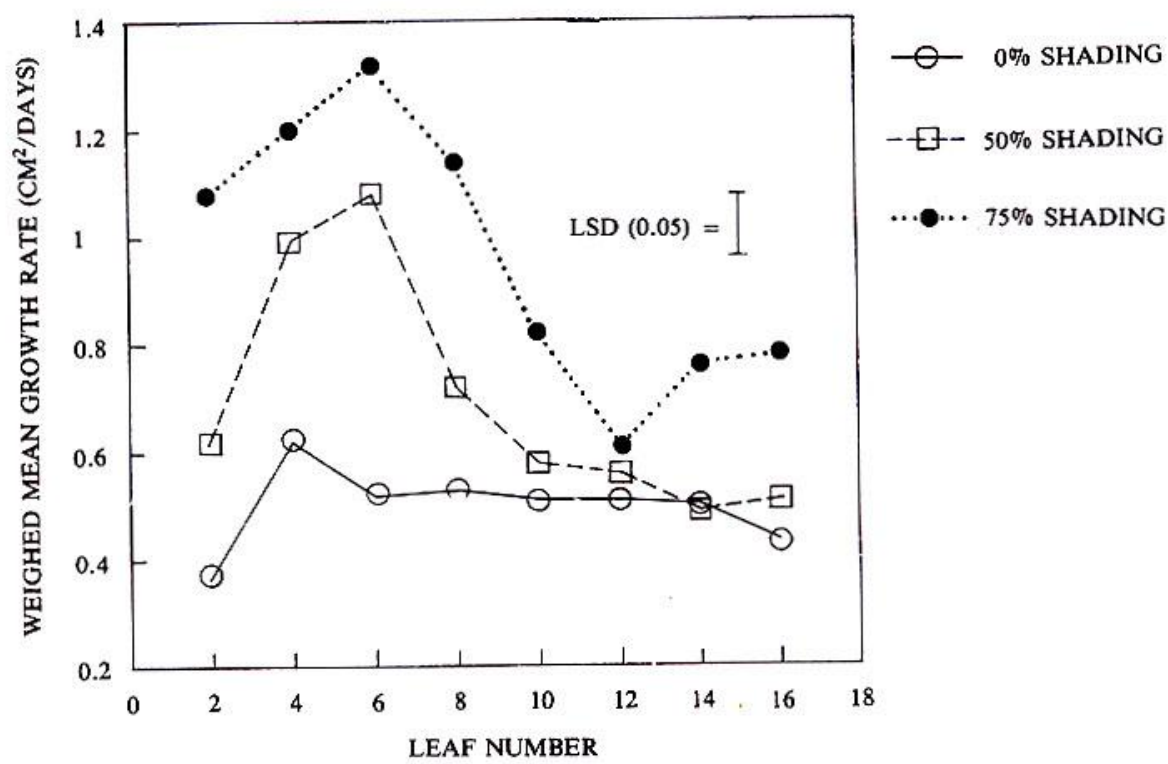

Figure 7. Effect of shading on weighed mean growth rate of $P$. conjugatum leaves 


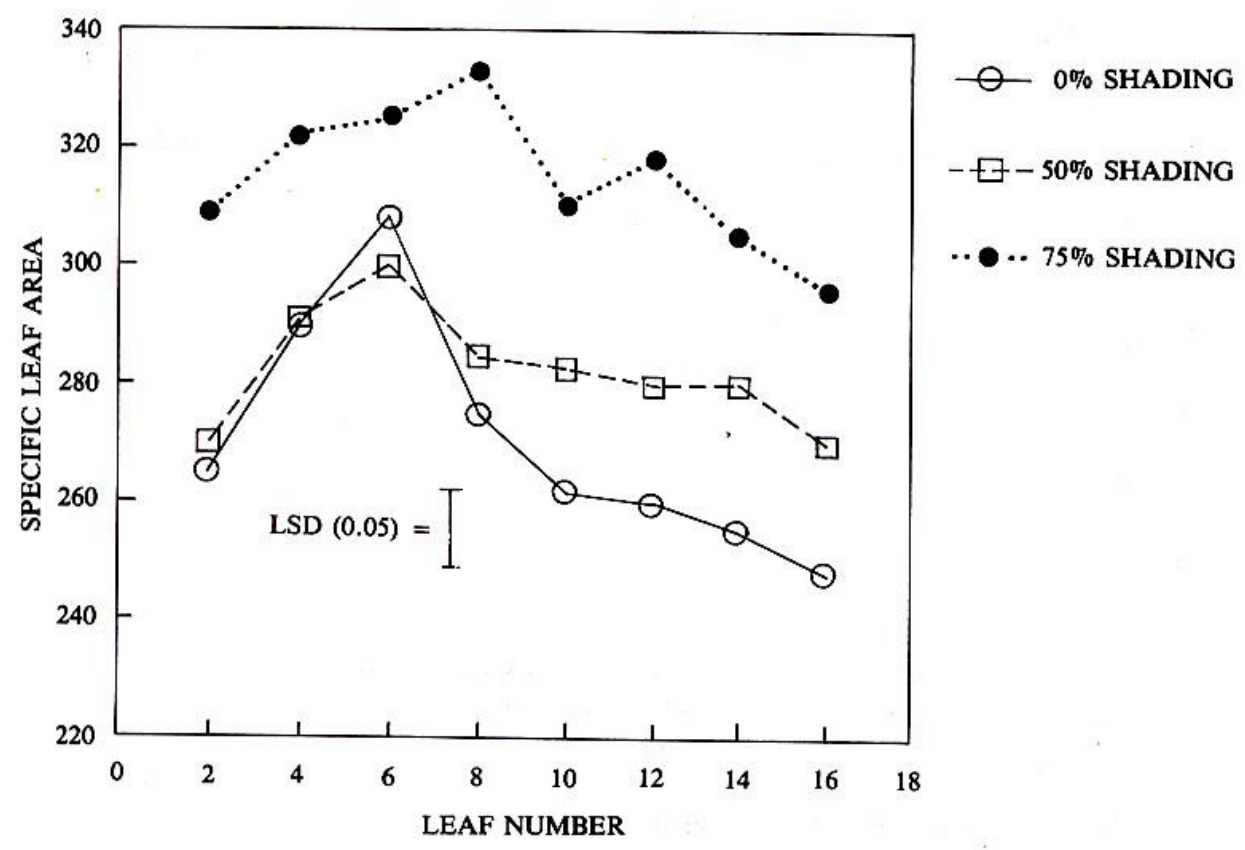

Figure 8. Effect of shading on specific leaf area P. conjugatum

increase in a specific area depended on the leaf position that tended to decrease as the leaf number increased. Plants grown in shade typically have lower maximum photosynthetic rates than plants grown in full light condition. Patterson (1980a) showed that shaded plants normally have lower rates of dark respiration which result in conservation of the photosynthates produced. As a result of the lower respiration rates, shade-grown plants typically have a lower light compensation point, the light level at which respiratory carbon dioxide loss equals photosynthetic carbon dioxide uptake and no net carbon dioxide exchange occurs.

\section{REFERENCES}

BJORKMAN, O. 1968. Further studies on differentiation of photosynthetic properties in sun and shade ecotypes of solidago virgaures L. Physiol. Plant, 21: 84-89.

BJORKMAN, O., and P. HOLMGREN. 1966. Adaption to light intensity in plants native to shaded and exposed habitats. Physiol. Plant, 19: 854-914. 
Shading effects on growth and partitioning of plant biomass - I.B. Ipor \& C.E. Price

BLACKMAN, G.E. and J.N. BLACK. 1959. Physiological and ecological studies in the analysis of plant environment. XI. A further assessment of the influence of shading on the growth of different species in the vegetative phase. Ann. Bot. 23: 51-63.

DALE, M.P., and D.R. CAUSTON, 1992. The ecophysiology of Veronica chamaedrys, V. montana and V. officinalis. II. The interaction of irridiance and water regime. Journal of Ecology 80(3): 493 - 504.

DENNET, M.D., J., ELSTON and J.R. MILFORD. 1979. The effects of temperature on the growth of individual leaves of Vicia faba L. in the field. Annals of Botany, 43: 197-208.

HOLM, L.G., D.L. PLUCKNETT, J.V. PANCHO, and J.P. HERBEROER, 1977. The World's Worst Weed. Distribution and Biology., University Press of Hawaii, p. 609.

ISHIMINE, Y.K., K. MIYAZATO, and S. MATSUMOTO. 1985. Physiological and ecological characteristics of weeds of sugarcane fields in the Ryukus Islands. 3. Effects of shading on growth and seed production of Paspalum urvellei Steud. Weed Res. (Japan) 30: 148-150.

KVET, J., J.P. ONDOK, J. NECAS and P.O. JARVIS. 1971. Method of growth analysis In Plant Photo-synthetic Production : Manual of Methods, eds. Z. Sestak, J. Catsky and P.O. Jarvis, W. Junk. N/V Publ. The Hague: 343-391.

MILFORD, G.F.J., T.O. POCOCK, J. RILEY and A.B. MESSEM, 1985. An analysis of leaf growth in sugarbeet. Leaf expansion in field crops. Annals of Applied Biology 106: 187-203.

MOOSAVI-NIA, H. and J. DORE. 1979. Factors affecting glyphosate activity in Imperata cylindrica L. Beauv. and Cyperus rotundus L. II. Effect of shade. Weed Res. 19: 321-327.

MORGAN, D.C. and H. SMITH. 1978. Linear relationship between phytochrome photoequilibrium and development in light grown Chenopodium album L. Planta 142: 187-193.

MORGAN, D.C. and H. SMITH. 1981. Control of light. The effect of light quantity (total influence rate) and light quality (red : far-red ratio) New Phytologist 88: 239-248.

NEWTON, P. 1963. Studies on the expansion of the leaf surface. II. The influence of light intensity and photoperiod. J. Exp. Bot. 14: 458-482.

PATTERSON, D.T. 1980a. Light and temperature adaption p. 205-235. In Predicting Photosynthesis for Ecosystem Model eds. J.D. Hesketh and J.W. Jones, Vol. 1 CRC Press, Inc. Boca Raton, F.L.

PATTERSON, D.T. 1980b. Shading effects on growth and partitioning of plant biomass on cogon grass (Imperata cylindrica) from shaded and exposed habitat. Weed Sci. 28: 735-740.

PATTERSON, D.T., C.R. MEYER, E.P. FLINT and P.C. QUIMBY, 1979. Temperature response and potential distribution of itchgrass (Rottboellia exaltata) in the United States. Weed Sci. 27: 77 - 82.

SOERJANI, M. 1970. Alang-alang, Imperata Cylindrica (L.) Beauv. (1812). Patterns of growth as related to its problem of control. BIOTROP Bull. No. 1.

THIAGARAJAH, M.R. and L.A. HUNT, 1982. Effect of temperature on leaf growth in corn (Zea mays). Canadian J. of Botany 60: 1647-1652.

VINCE-PRUCE, D. 1977. Photo control of stem elongation in light growth plants of Fuchsia hybrids. Planta 133: $149-56$.

WARD, D.A. and H.W. woolhouse, 1986. Comparative effects of light during growth on the photosyntetic properties of NADP-ME type $\mathrm{C} 4$ grasses from open and shaded habitats. Gas exchange, leaf, anatomy and ultra structure. Plant, Cell and Environment 9: 261 -270.

YeGAPPAN, T.M., D.M., PATTON, C.T. GATES and W.J. MULLER, 1982. Water stress in sunflower (Helianthus annuus L.) II. Effect of leaf cells and leaf area. Annals of Botany 49: 63-68. 